\title{
Implementation of service profit chain initiatives in a franchise system
}

\author{
Alex Maritz, Faculty of Business and Enterprise, Swinburne University, \\ Hawthorn, Australia \\ Gideon Nieman, Department of Business Management, University of \\ Pretoria, Pretoria, South Africa
}

\begin{abstract}
Purpose - The purpose of this paper is to evaluate the implementation of the service profit chain as an entrepreneurial marketing initiative within a defined franchise system. An objective is also to evaluate these initiatives against service quality dimensions. Despite recognition of the merits and advantages of service profit chain initiatives of retention, related sales and referrals, little research has empirically addressed the perceptions of franchisees regarding these initiatives.

Design/methodologylapproach - Methodology includes the empirical analysis of evaluating the effectiveness of service profit chain implementation, primarily based on initiatives of retention, related sales and referrals. Research methodology comprises the survey approach, using electronic media and Surveypro analysis. This is facilitated by descriptive and inferential statistical techniques using SPSS version 11.0 data analysis. Inferential significance tests include the ANOVA Kruskal-Wallis hypothesis test; and the Cronbach's coefficient alpha.
\end{abstract}

Findings - Hypothesis tests highlight the significance of a positive association between service profit chain initiatives and service quality. All service profit chain initiatives were deemed appropriate. Item analysis highlights specific dominant service profit chain initiatives, linking key relationship marketing and service quality themes.

Research limitations/implications - Findings are indicative of implementation opportunities, including measurement of loyalty within the system, developing customer feedback and complaint systems, and communicating the value of service profit chain enhancement within the franchise system.

Originality/value - Originality includes cognizance of entrepreneurial orientation, relationships and service quality when implementing service profit chain initiatives. Concurrent research opportunities include the implementation of other entrepreneurial marketing initiatives, including relationship marketing and benchmarking for best practice.

Keyword(s):

Profit; Service levels; Retention; Sales.

An executive summary for managers can be found at the end of this article 


\section{Introduction}

The aim of this study is to evaluate service profit chain initiatives in a defined franchise system in the home entertainment industry. The objective is to identify the relationship between the service profit chain initiatives and service quality, highlighting opportunities and implications for managers in similar service organizations. Existing research on the service profit chain is dominant in service related industries, yet scant regarding the perception of franchisees in a franchise system. Existing research is predominantly end- user or customer focused, and lends little with regard to franchise system participants. The purpose of this research project is to identify the effect of service profit chain initiatives as perceived by franchisees. Service profit chain initiatives are dominated by retention, related sales and referral strategies, whereas service quality measures include responsiveness, assurance, tangibles, empathy and reliability. The defined franchise system is the market leader in the home entertainment industry on the Africa continent, characterized by high growth, innovation and creativity. Whilst franchising may be seen as an entrepreneurial option enabling the creation and development of ventures, this study involves the sustainability of such ventures. Sustainability includes implementation of appropriate marketing initiatives, such as the service profit chain. Cognizance must however be taken of other marketing initiatives in the system, such as relationship marketing, service quality and best practice initiatives.

We review current literature on generic franchising, the service profit chain and service quality. The next stage is the identification and evaluation of distinct service profit chain initiatives within a defined franchise system, followed by empirical analysis of such initiatives. We conclude by synergizing the implementation of service profit chain initiatives and service quality within the franchise system.

\section{Literature review}

Franchising is an entrepreneurial option toward the creation and development of ventures (Bygrave, 1997). Michael (2003) mentions franchising as a technique for entrepreneurs in service industries to assemble resources in order to rapidly create large chains and gain first mover advantage. Franchisors in many sectors have recognised the benefits of multiple-unit franchisees (Johnson, 2004), and this is seen as an entrepreneurial continuation of the franchise trend. Multipleunit franchisees are those franchisees with two or more franchised units (outlets) within a franchised system. These franchisees exhibit distinctive differences regarding an entrepreneurial orientation (EO) compared to that of single unit franchisees (Maritz, 2005a). Entrepreneurial orientation refers to those character themes and personality attributes associated with entrepreneurial activity, such as innovation, creativity, risk-taking and proactivity (Bolton and Thompson, 2004). The entrepreneurial orientation of the franchisor is not disputed (Lindsay and McStay, 2004), whereas there has been dispute regarding the EO of 
franchisees. Recent empirical studies identify the lack of a significant EO among franchisees, despite significant EO among multiple-unit franchisees (Maritz and Nieman, 2005).

Despite varying levels of EO within a franchise system, the success of the system is dependant on a conscious effort from franchise system participants (Mendelsohn, 2003). Only franchisors with successful franchisees succeed, and this is due to the importance of relationship marketing in the system (Lindsay and McStay, 2004). Relationship marketing is a distinct requirement in all organisations wishing to achieve customer satisfaction and loyalty (Heskett, 2002). Relationships are integrated within the service profit chain, identifying the management of marketing initiatives between all supply and value chain participants (Maranto and Reynoso, 2003).

The service profit chain is a well-received model to explain the sustainable competitiveness of many service organisations (Lau, 2000, p. 422). The model attributes a service organisation's financial and market performance to its relationships with its customers and employees (Heskett, 2002). Internal service quality serves as the foundation of the model, igniting a chain effect to an organisation's growth and profit (Silvestro, 2002). The service profit chain is a strategic service vision, whereby there is a strong and direct relationship between customer satisfaction (Andreassen, 1994), customer loyalty (de Ruyter and Bloemer, 1999) and the value (Silvestro and Cross, 2000) of goods and services delivered to customers. In addition, the model also highlights links between customer satifaction and employee loyalty and satisfaction (Heskett, 2002). Furthermore, there is a strong link between these elements and overall profit and growth of an organisation (Heskett et al., 1997). Organisational profit and growth are linked to customer loyalty, satisfaction and value via the strategic implementation of referral, related sales and retention strategies (Heskett et al., 1994).

In contrast to economic market forces (Porter, 1998), whereby competitors believe a high correlation between profitability and market share prevail, many management authors (Reichheld and Sasser, 1990) are of the opinion that it is quality of market share which is important (Andreassen, 1994), and a high correlation actually occurs between service value and profitability (Maranto and Reynoso, 2003; Ho and Cheng, 1999). Quality of market share depicts a value add approach, as appose to pure volume share of the market (Heskett et al., 1994). This correlation was evident in Southwest Airlines (USA), who never made the top five largest in its industry, but has over the years been the most consistently profitable (Herbert D. Kelleher, Chairman, President and CEO of Southwest Airline Company). The Service profit chain identifies direct and strong relationships between profit, customer satisfaction, employee satisfaction and capability (Heskett et al., 1994). 
The customer value equation is pivotal to the other two elements of the service profit chain, with the employee at one end, and the customer at the other ( $\mathrm{Ho}$ and Cheng, 1999). The employee links productivity and quality of output with employee loyalty, satisfaction and capability (Andreassen, 1994; Silvestro, 2002). The customer value equation equates results plus process quality against price plus customer access costs, linking profitability and growth with customer satisfaction and customer loyalty (Ruyter and Bloemer, 1999). In service settings, these relationships are self-reinforcing; whereby satisfied customers contribute to employee satisfaction and vice versa (Reichheld, 2001).

\section{Retention strategies}

Retention can be defined as a commitment by customers to do business or exchange with a particular company on an ongoing basis (Zineldin, 2000). Customer retention brings with it benefits such as employee retention and satisfaction, better service, lower costs (Reichheld, 1996), lower price sensitivity, positive word-of-mouth, higher market share, higher efficiency and higher productivity (Zineldin, 2000). Retention of current customers refers to the ability of organisations to maintain active relationships with their current customer base (Ruyter and Bloemer, 1999). In return, the revenue received becomes increasingly profitable, due to less effort required to analyse their needs (Andreassen, 1994). MBNA (USA), a large insurance company, had one of the lowest defection rates in the industry, and as a result, achieved phenomenal profits, despite no acquisitions or mergers.

The higher the employee and customer retention rates (loyalty) the higher the profit (Palmer, 2001). Not paying attention to all major stakeholders' results in a hidden cost to cash flow resulting from the churn in fickle customers, disinterested employees and short-term owners. While satisfaction may be an important retention driver, trust and brand switching barriers are also likely to influence retention, both independently and in tandem (Ranaweera and Prabhu, 2003). In their empirical investigation on the effect of these constructs on retention, the following were highlighted:

- In a low customer contact, mass service setting, satisfaction is the strongest driver of customer retention.

- Results confirm the expected positive effect of trust on retention.

- No evidence that trust, as a direct determinant of retention, is more important than satisfaction, not even in a continuous purchasing setting more suited to trust relationships.

- Trust can be lost in the event of service failure, despite a satisfying service recovery experience.

- Customers appear to be willing to accept the apology and compensation offered by the service provider to offer a trouble free service in the future.

- The main and the interaction effects of switching barriers on retention were highly significant. The suggestion is that, in an industry with 
switching barriers, service providers are likely to be able to retain even those customers who are less than satisfied.

- Customers could become resentful to switching barriers especially if these barriers lead to a scenario of complete entrapment.

- While switching barriers could be thought of as an alternative means of retaining customers, they could also be a complementary source of satisfaction through the provision of added value to the service bundle.

\section{Related sales}

It is more profitable to sell new products and services to the existing customer base than to new customers (Reichheld, 2001). Given the existence of a loyal customer base, there is a strong incentive to exploitation, by developing related products and services that appeal to it (Heskett et al., 1997). Many companies have diversified to accommodate related sales, thus enhancing their product offering, in turn improving profitability (Gibson, 1998). Whilst Ster-Kinekor theatres are in the business of movie exhibition, their related services include the sale of confectionery items, which account for 27 per cent of their profits. Whilst related sales are directed at the lifetime customer, organisations may be in the position to leverage their core product (Porter, 1998), whereby additional revenue streams may be introduced. These streams are not always directed at the customer. Such leverage occurs at Ster-Kinekor theatres, where substantial revenues are a result of advertising opportunities within theatres and theatre foyers (CineMark). Similarly, Exclusive Books have introduced coffee shops in all their outlets; affording their customers the opportunity of reading books in a friendly and convenient location. The related-sales concept in this case enhances the total customer offering.

From a strategic marketing perspective, related sales may be aligned to extending volume growth via extended usage in current markets (Walker et al., 1999). The aim is to get current customers to spend more, either by increasing consumption on current products or services, or introducing new products or services (Kotler, 2000). Implementation may centre on affordability, convenience, needs, complementarity, notwithstanding impulse purchases. Whilst related sales are aimed at an existing customer base (lifetime value), increased penetration and market expansion are not relevant in this case. A study of purchase intentions in the home entertainment industry (Maritz, 2002, 2003a, 2003b) found that customers had idle cash on hand once receiving change from instore purchases. The objective was to convince the customer to spend that change instore; via related sales of confectionery, phone cards, movie paraphernalia and accessory items.

\section{Referrals}

Referral is used to describe communications (either positive or negative) between groups such as the product provider, independent experts, family and 
friends and the actual or potential consumer. Word-of-mouth is a similar concept, except that it constitutes verbal communication. Referrals from existing customers to other consumers rate amongst the highest form of positive communication (Stokes and Lomax, 2002). This necessitates efforts to enhance customer satisfaction, not only for repeat business, but also for the high value of referrals (Soderlund, 1998). Reichheld and Sasser (1990) found that recommendations from friends and acquaintances carry twice the impact of paid advertising when consumers make purchasing decisions. The US Office of Consumer Affairs identified that dissatisfied customers tell at least 11 other people of their dissatisfaction, whereas satisfied customers only tell five other people of their satisfaction (Heskett et al., 1997). Reichheld (2001) reported that research indicates that people only tell eight friends about a truly satisfying experience, whilst a bad experience may be communicated to 12 people. Soderlund (1998) is of the opinion that the explanation is due to the theory of asymmetrical effects of positive and negative events. Word-of- mouth (WOM) is regarded as the primary referral medium (Ennew et al., 2000).

Zeithaml and Bitner (2003) believe that people regularly turn to others for information rather than to traditional marketing channels; which may be due to services often being high in experience and credence properties. Referrals from satisfied customers go a long way in developing the trust needed for a new customer to purchase a service that may appear risky (Heskett, 2002). Word-ofmouth is considered more credible than other sources of information, and satisfied, loyal customers are likely to provide an organisation with strong wordof-mouth endorsements (Zeithaml and Bitner, 2003). Palmer (2001) recommends that opinion leaders be used to convey positive word-of-mouth, as this is seen as credible to the consumer.

\section{Service quality}

Service quality is often conceptualised as the comparison of service expectations with actual performance perceptions (Zeithaml and Bitner, 2003). Emphasis is placed on the combined attitudinal construct of service quality, highlighting constituents of both cognitive and affective components. Parasuraman et al. (1998) tend to delineate service quality using more cognitive items, whereas Edwards (1990) found that the affective attitudes exhibited more change under affective means of persuasion than under cognitive means of persuasion. Teas (1993), however, argues that service quality is a combination of transaction and overall attitude.

Research suggests that customers perceive quality in a multi-dimensional way, based on multiple factors relevant to the context (Zeithaml and Bitner, 2003). The early works of Berry et al. (1985) provide a strong foundation for understanding the dimensionality of service quality. Their original qualitative study identified ten key dimensions, each of which relates not only to the service consumed, but also to the customers' confidence in those providing the service. These included 
tangibles, reliability, responsiveness, competence, courtesy, credibility, security, access, communication and empathy. Over the years, the authors have distilled this list into five broader categories. These dimensions represent how consumers perceive service quality, and may use all or a combination of dimensions (Berry et al., 1985). Widely referred to as SERVQUAL, the five elements include reliability, assurance, tangibles, empathy and responsiveness.

Service quality measurement includes analyses of a number of tools, including SERVQUAL (Parasuraman et al. 1998); SERVPERF (Cronin and Taylor, 1992); EP/NQ model (Teas, 1993); Qualitometro (Franceschini et al. (1998); critical factor approach (Sureshchandar et al., 2002); bank service quality (Bahia and Nantel, 2000); and two-way model (Schvaneveldt et al., 1991). It is proposed that each is applicable under prescribed circumstances, with SERVQUAL dominating the research project at hand.

\section{Objective and hypothesis}

The objective of this research is to determine the relationship and association of service profit chain initiatives to overall service quality. In addition, another goal was to determine the importance of the three service profit chain initiatives (retention, related sales and referrals), as perceived by members of the franchise system (franchisees).

The hypotheses being tested are:

$H 1$. Service profit chain initiatives are positively associated with service quality.

HO. Service profit chain initiatives are not positively associated with service quality.

Hypotheses testing include non-parametric testing, indicative of the assumption that the dependent variable does not necessarily have a normal distribution (bellshaped). Hypothesis tests produce $P$-values, measuring significance, whereby there is a chance that the null hypothesis is true. Hypothesis tests will include the Kruskal-Wallis one way ANOVA test, together with interaction tests for greater than one independent variables. Service quality, the dependent variable, was measured using similar inferential statistics as the stated hypothesis.

\section{Methodology}

\section{Design process}

This research project was conclusive in nature; where the primary objective was to test the hypothesis of service profit chain initiatives in relation to service quality. This however did not negate the use of exploratory data, originally used in this study to develop hypotheses and develop questions (framework). 
Secondary data includes available literature on the service profit chain, service quality and the franchise paradox. Primary data consists of the collection of data from the defined franchise system, with the objective of making inferences regarding the results. Validity and reliability are indicative from the high response rate, coupled with appropriateness to the study at hand.

\section{Data collection}

The relationship between qualitative and quantitative research should not be considered in terms of a mutually exclusive dichotomy but rather as a continuum of complementary paradigms. The applicability of the current research project is quantitative in nature, despite the advantages and merits of qualitative research being complementary. The two were synergized, evaluated and then determined to construct a niche setting with clear research objectives. Qualitative data was primarily used during the exploratory phase, followed by quantitative primary data to test hypotheses. The survey method was identified as the preferred format of data collection. The approaches identified by Malhotra et al. (2001), Aaker et al. (2001) and the tailored design method of Dillman (2000) were instrumental in the design of the survey applicable to the research project on hand. The sampling plan consisted of a census of all 125 franchised outlets within the system. As such, research methodology comprised the survey approach, using electronic media and Surveypro analysis. Measurement scales involved a bi-variate measurement approach, that of nominal and interval measurement scales. Use was made of a standard five-point Likert-scale, facilitating consistency and ease of completion. The research project on hand is part of a wider service initiative project, which includes facets of entrepreneurial orientation, relationship marketing and best practice. The questionnaire depicts ten items identified as appropriate to present service profit chain initiatives of retention, related sales and referrals. The items (numbers 39 to 48 ) represent themes of service profit chain associations, including customer satisfaction, best practice, feedback, quality of work life, relationships, lifetime value and word of mouth. Associations are depicted in Table I. Applicable questions are represented in Table II, with representation as follows:

- Service profit chain (Q39-48).

- Service quality (Q49-58).

- Relationship marketing (Q59-68).

- Best practice (Q69-78).

Questions 1-38 represented franchise paradox questions, used as complementary data for the study on hand.

\section{Empirical descriptive and inferential statistics}

The Surveypro analysis was facilitated by descriptive and inferential statistical techniques using SPSS version 11.0 data analysis. Inferential significance tests 
include the ANOVA Kruskal-Wallis hypothesis test; based on the approximation of the chi-square distribution with $k-1$ degrees of freedom. Internal-consistency reliability is measured by the Cronbach's coefficient alpha, measuring overall inter-item correlation between the identified constructs. Exploratory research, in the form of the literature review and previous empirical studies, are used as background and facilitating data. Service profit chain initiatives, as identified by Heskett et al. (1997) were adapted as measurement tools for the research project at hand. A ten point association is implemented to empirically evaluate service profit chain initiatives and service quality (Table II). The defined franchise

system is prominent market leader in the home entertainment industry, consisting of a franchise base of 150 franchisees. An appropriate response from 62 percent of franchisees was recorded. Service quality is measured by a combination and integration of SERVQUAL and SERVPERF methodology, in relation to service profit chain initiatives. The Pearson correlation coefficient was deemed appropriate for the study.

\section{Data analysis}

\section{Descriptive results}

Regional response and realization rates consisted of 93 responses, indicative of an 84 percent response rate. Highlights included a dominant male response (73, 4 per cent), which is in line with the demographics of the franchise base. The regional response and realization rates are depicted in Table III. Outlet representation identifies 72,8 per cent of franchisees having only one outlet, indicative of the lack of a significant entrepreneurial orientation among franchisees (empirical investigation in a wider study in the franchise system; Maritz, 2005b).

Associated themes within the construct include SPC links, retention, related sales and referrals. Item descriptive statistics are depicted in Table I. The left hand column identifies the service profit chain associations of SPC links, retention, related sales and referrals. The descriptive and inferential statistics are used for an analysis on a per item basis. Correlation analysis is carried out to evaluate associations within the construct, together with associations of service quality.

Construct descriptives are characterized by a mean score of 3.38; representing a favourable response to the construct questions. The standard deviation for the 
Table I Service profit chain descriptive statistics

\begin{tabular}{llccccc}
\hline Question & Association & Item mean & $\begin{array}{c}\text { Std error } \\
\text { of mean }\end{array}$ & $\begin{array}{c}\text { Standard } \\
\text { deviation }\end{array}$ & $\begin{array}{c}\text { Alpha if } \\
\text { Kurtosis }\end{array}$ & $\begin{array}{c}\text { Item-scale } \\
\text { correlation }\end{array}$ \\
\hline 39 & SPC links (satisfaction 1) & 3.75 & 0.086 & 0.820 & 1.460 & 0.6755 \\
item deleted
\end{tabular}

\section{Table I Service profit chain descriptive statistics}

Table II Strategic service questionnaire

\section{Questions}

39. Customer satisfaction leads to long-term profitability of your franchised outlet/s

40. Employee satisfaction leads to customer satisfaction

41. The Mr VIDEO franchise system encourages franchisee best practice exchanges and interaction

42. The Mr VIDEO franchise system has optimal customer feedback, complaint and suggestion systems

43. Empowering employees and enhancing quality of worklife lead to employee loyalty

44. My outlet/s maintain active relationships with current customers

45. My outlet/s concentrate on retaining existing customers

46. My customers are encouraged to purchase related services, such as confectionery and video accessories

47. My outlet/s implement strategies to encourage referral and word of mouth communication

48. My outlet/s measure the lifetime value of customers (loyal customers who return time after time)

\section{Statements}

49. My outlet/s deliver on customer promises

50. My outlet/s perform the service right the first time

51. Employees of my outlet/s are always willing to help customers

52. Employees of my outlet/s provide prompt service

53. Customers feel safe in their transactions with my outlet/s

54. The behaviour of employees in my outlet/s instils confidence in customers

55. My outlet/s have the customers' best interest at heart

56. My outlet/s have employees who give customers individual attention

57. My outlet/s' physical facilities are visually appealing

58. It is realistic to expect my outlet's employees to know what the needs of the customer are

59. My outlets achieve competitive advantage against opposition home entertainment outlets through improved customer interaction and responsiveness

60. My outlet/s are prone to relationship focus as opposed to transaction focus

61. Superior supplier relationships add value to my outlet's service offering

62. The supply chain relationships between the Mr VIDEO system and the major suppliers are built on trust and reciprocity

63. Marketing orientation and marketing culture of my outlet/s influence positiveness about the organisation (Mr VIDEO franchise system)

64. Retaining existing customers leads to customer loyalty and lifetime customers

65. Internal marketing initiatives such as enhancing internal quality of work-life are encouraged by my outlet/s

66. Franchise system relationships between franchisee and franchisor are an integral component of Mr VIDEO internal marketing and communication

67. My outlet/s have optimal associations and alliances with other industry participants

68. Mr VIDEO franchise measures franchisee satisfaction levels

69. My outlet/s continually evaluate their markets and customers

70. My outlet/s have a developed vision and strategy in the long term

71. My outlet/s focus product and service offerings on customer satisfaction through meeting or exceeding expectations

72. My outlet/s believe that strong focus on community involvement drives awareness and loyalty

73. Direct mail is used as a cost-effective tool used to drive frequency of active and inactive customers

74. Strong relationships and loyalty are developed between employees and customers of my outlet/s through consistency of management and staff

75. A pleasing outlet is important for keeping your customers coming back

76. I regularly remodel and update my outlet/s to reinforce a strong and positive image to customers

77. My outlet/s' operating procedures are clearly documented for consistency of execution from staff in an operations manual

78. Mr VIDEO franchise encourages the communication of best practice initiatives within the franchise system

Table II Strategic service questionnaire 
Table III Regional response and realization rates

\begin{tabular}{|c|c|c|c|c|c|}
\hline Region/province & Franchisees & Outlets & Average outlets per franchisee & Response counts & Response (\%) \\
\hline Western Cape & 35 & 64 & 1.8 & 32 & 91.4 \\
\hline Gauteng & 35 & 46 & 1.3 & 27 & 77.1 \\
\hline Eastern Cape & 12 & 14 & 1.2 & 11 & 91.6 \\
\hline KwaZulu Natal & 7 & 10 & 1.4 & 6 & 85.7 \\
\hline Limpopo & 4 & 5 & 1.3 & 4 & 80.0 \\
\hline North West & 5 & 7 & 1.4 & 4 & 80.6 \\
\hline Free State & 5 & 8 & 1.6 & 4 & 80.0 \\
\hline Mpumalanga & 4 & 4 & 1.0 & 3 & 75.0 \\
\hline Northern Cape & 3 & 4 & 1.3 & 2 & 66.7 \\
\hline Total & 110 & 162 & 1.4 & 93 & 84.6 \\
\hline
\end{tabular}

Table III Regional response and realization rates

sample mean, referred to as the standard error of the mean, is relatively small for the $n=93$ response rate; an indication that the average deviation from the mean is relatively stable. Standard deviations are relatively low (all variables below 1.0), indicative of the majority of responses distributed closely around the mean score. Kurtosis is indicative of a fairly normal distribution, with the exception of variable 44. Excluding variable 44 would result in a construct kurtosis of 2.30 , being more representative of the data set. A total of 70 per cent of the variables are characteristic of a peaked distribution, whilst 20 per cent have a distribution marginally flatter than a normal distribution.

\section{Inferential statistics}

Table I also identifies an appropriate construct Cronbach's Alpha of 0.8335 (above desired 0.7). The distribution is also characterised by appropriate reliability should any item be deleted. Item-scale correlations are also all appropriate (above 0.3 ). The result is therefore the inclusion of all service profit chain items.

\section{Item analysis}

Item analysis was conducted per item, representative of questions 39 to 48 of the questionnaire (Table II). This was analysed within the item associations depicted in Tables I and III. Once all items were evaluated, the hypothesis is tested using the non-parametric ANOVA Kruskal-Wallis test.

\section{SPC links (satisfaction 1 and 2)}

Questions 39 and 40 refer to the SPC association of satisfaction. The two items have similar descriptives, with the former representing customer satisfaction, and the latter representing employee satisfaction. Correlated item-total correlation for each variable is high (both in excess of 0.61 ); with coefficient alpha being reduced if any of the items are deleted. The two items are significantly correlated (0.784 at 0.01 level). The associated mean of the two variables is 3.87 : 
1. SPC links (satisfaction 1): 66 per cent of respondents are in agreement with the variable (29 per cent neutral response), representative of a mean score of 3.75. A relatively flat distribution with moderate standard deviation (96 per cent of responses within three scales) is realised. Inter-construct significant correlations (0.01 level) include QWL (Q43), relationships 1 and 2 (Q44 and 45), WOM (Q47) and lifetime value (Q48). The most significant of the inter-construct correlations is that with the other satisfaction variable (Q39). The satisfaction 1 variable also has the second highest item-total correlation in the construct (0.6755). Significant correlations in the service quality construct ( 0.01 level) include all variables in the construct (Q49-58); with an average correlation of 0.542 at 0.01 level. Significant correlations in the relationship marketing construct include customer markets 1 (Q59), internal markets 1 and 3 (Q61 and 65), and referral markets 1 and 2 (Q63 and 64). Significant correlations with the best practice construct include all variables with the exception of questions 69, 70, 73 and 77.

2. SPC links (satisfaction 2): 89 per cent of respondents are in agreement with the link between employee and customer satisfaction. A high mean score of 3.99 is realised, with a small standard deviation, attributable to 89 per cent of responses within two scales. This in turn results in a peaked distribution (Kurtosis of 5.842). Inter-construct correlations parallel those of the satisfaction 1 variable, correlating significantly with the same variables. Significant correlations $(0.01$ level) with the service quality construct also include all variables; with an average correlation of 0.535 at 0.01 level. Significant correlations across the relationship management construct include all variables with the exception of questions 62,67 and 68. Significant correlations across the best practice construct include refining offerings (Q71), implementing the marketing plan 1 and 3 (Q72 and 74), promotion and in-store merchandising (Q75) and clear in-store operations (76).

The two satisfaction variables correlate significantly to the service quality variables, which is indicative of a positive association. The other variables of the SPC are now evaluated to establish inter-construct associations; together with appropriate associations with other construct variables.

\section{SPC links (best practice)}

Question 41 of the questionnaire measures the perception of franchisees with regard to the encouragement of best practice exchanges. A total of 56 per cent of franchisees responded negatively to this variable (29 per cent neutral). The result is a relatively low mean score of 2.49 , and correspondingly high standard deviation. The curve is marginally flatter than a normal distribution $(-0.320)$. Inter-construct significant correlations (0.01 level) are limited to feedback (Q42) and lifetime value (Q48). Significant correlations with the SQ construct include responsiveness 1 (Q51) and tangibles (Q57). Relationship marketing construct 
significant correlations include customer markets (Q59), internal markets 1 and 2 (Q61 and 62), referral markets 1 (Q63) and recruitment markets (Q68). Best practice construct correlations include all but three variables (Q71, 72 and 75).

\section{Retention (feedback)}

The feedback variable is one of four related retention variables within the construct. The variable evaluates effective customer feedback as a retention initiative. It has the lowest mean score response in the construct (2.20), with 74 per cent of franchisees responding negatively to the question (Q42). Only 7 per cent of respondents are in agreement with the system having optimal customer feedback channels (20 per cent neutral response). A total of 81 per cent of responses are across two scales, representative of a relatively small standard deviation. The item-scale correlation is only just appropriate for construct reliability (0.2935); with an appropriate alpha coefficient should the item be included. Significant inter-construct correlation ( 0.01 level) is only apparent with the retention association of lifetime value (Q48). The variable does not significantly correlate with the SQ construct, with the exception of reliability 2 (Q50). Relationship marketing variables significantly associated include internal markets 2 (Q62) and recruitment markets 2 (Q68). Best practice construct variables significantly correlated with the feedback variable include understanding customer markets (Q69), developing strategy and vision 1 (Q70), implementing the marketing plan (Q73), clear in-store operations 1 and 2 (Q76 and 77) and developing strategy and vision 2 (Q78).

\section{SPC links (quality of work life-QWL)}

A total of 68 per cent of franchisees are in agreement with the positive effect of quality of work life on employee loyalty. A total of 27 per cent of respondents however were neutral in response. A high mean score of 3.67 is characterised by a peaked distribution with relatively small standard deviation. Inter-construct significant correlations ( 0.01 level) include all variables with the exception of the feedback variable (Q42). The QWL variable has a high item-total correlation of 0.6328 . Significant correlations ( 0.01 level) in the SQ construct are across all variables, with the most significant being responsiveness 2 (Q52). This association correlates QWL with employees providing prompt response. The significant correlations within the relationship marketing construct include customer markets 1 (Q59), internal markets 2 (Q62), referral markets 1 and 2 (Q63 and 64) and internal markets 3 (Q65). Best practice significant correlations are found in refining offerings (Q71), implementing the marketing plan 1 and 3 (Q72 and 74), promotions and in-store merchandising (Q75) and clear in-store operations (Q76). The above associations all include a link between employees and QWL. 


\section{Retention (relationships 1 and 2)}

These two closely associated variables are represented in questions 44 and 45 of the questionnaire (respectively). The questions directly relate to relationships and retention of existing customers. The two variables have item-total correlations within the top quarter in the construct, well above the appropriate level ( 0.6097 and 0.6328 respectively). Next to the satisfaction 1 and 2 correlation, the relationship variables portray the second most significant correlation $(0.715$ at 0.01 level). Should either of the variables be deleted from the construct, the total Cronbach's Alpha will be reduced, hence the appropriateness of including the two variables. The two variables have a high mean score between 3.90 and 3.95; and correspondingly low standard deviations. Agreement responses are in excess of 76 per cent of franchisees, representative of peaked distributions (kurtosis of 10.21 and 5.109 respectively). Relationships 1 in particular, has an exceptionally peaked distribution, with 85 per cent of responses in one scale (agree). The two variables are significantly correlated (0.01 level) within the construct to all variables excluding best practice (Q41), feedback (Q42) and lifetime value (Q58). Both variables are significantly correlated to all variables within the service quality construct. Significant correlations in the relationship construct are shared between internal markets 1 (Q61), referral markets 2(Q64) and internal markets $3(Q 65)$. This association is attributable to strong links between retention, referrals and internal marketing initiatives. The two variables share an abundance of significant correlations with the best practice construct; refining offerings (Q71), implementing the marketing plan 1 and 3 (Q72 and 74), promotions and in-store merchandising (Q75) and clear in-store operations 1 (Q76). These associations are attributable to the as mentioned in the literature link of customer relationships and best practice initiatives.

\section{Related sales}

Question 46 of the questionnaire incorporates the broadened service offerings within the franchise system. A total of 67 per cent of franchisees are in agreement with the variable, with a resulting mean score of 3.68. The distribution is relatively peaked (kurtosis of 3.584) around the agree and neutral scales. An appropriate reliability Cronbach's Alpha is still maintained if the item is included in the construct. Inter-construct significant correlation is around satisfaction 1 (Q39), QWL (Q43), relationships 1 and 2 (Q44 and 45), and WOM (Q47). The referrals link is thus associated to SRC links and retention. Service quality construct correlations of significance (0.01) include reliability 1 (Q49), assurance 1 and 2 (Q53 and 54), and empathy 2 and 3 (Q56 and 58). These associations are attributable to related sales offering the customer a wider range of services, highlighting the caring and sharing initiative. Relationship marketing construct correlations are significant in customer markets (Q59), exhibiting related sales as a means of competitive advantage. The correlation is significantly demonstrated to the best practice construct in understanding customers and markets (Q69), 
developing strategy and vision 1 (Q70), refining offerings (Q71) and influencing the marketing plan 1 and 3 (Q72 and Q74).

\section{Referrals (word of mouth-WOM)}

Word of mouth communication is emphasized in question 47 of the questionnaire. The variable received a 64 per cent positive response, with a mean score of 3.62. The distribution is marginally peaked (kurtosis of 1.541) around the agree and neutral scales, also indicative of a relatively small standard deviation. Cronbach's Alpha is appropriate if the variable is not deleted. Interconstruct correlations are significant ( 0.01 level) across all variables with the exception of best practice (Q42) and feedback (Q42). Service quality correlations include significance across all variables. Relationship marketing construct correlation is significant through all variables, with the exception of internal markets 2 (Q62) and recruitment markets 2 (Q68). This highlights the retention association with the various relationship markets. Best practice construct correlations are significant in refining offerings (Q71), implementing the marketing plan 1 and 3 (Q72 and 74), promotions and in-store merchandising (Q75) and clear in-store operations 1 (Q76).

\section{Retention (lifetime value)}

The final construct question seeks perceptions of the measurement of lifetime customers. This variable raised a large neutral response ( 35 per cent). It appears that franchisees are uncertain how to measure the value of loyal customers. A total of 48 per cent of franchisees responded in disagreement, resulting in a mean score of 2.61. This represents a relatively flat distribution (kurtosis of 0.776 ), albeit only marginally positively skewed. The variable, however, elicits the highest item-total correlation within the construct (0.6831). The deletion of the variable decreases the reliability coefficient, hence the appropriateness of retaining the variable in the construct. Significant correlation (0.01 level) within the construct is experienced across all but two variables (Q44 and 46). Service quality significant correlations are experienced through all variables, demonstrating the association between service quality factors and customer loyalty. Relationship marketing construct correlation is significant across all but two variables (Q66 and 67). The best practice significant correlation to the lifetime value variable is evidence of all but two variables not being significant (Q72 and Q75).

The incident rate of substantial significant correlation to the service quality construct has been evaluated on an item to item basis. An additional item-total statistic was evaluated, comprising all variables within the service profit chain and service quality constructs (Q39-Q58). The reliability coefficient of all variables $(n=20)$ resulted in an overall alpha of 0.9367 , representative of appropriately high reliability. The only variable raising concern is question forty- 
two (feedback), however, the item-total correlation of 0.2595 is deemed appropriate as it has only a marginal effect on the overall Cronbach's Alpha.

\section{Service profit chain significance}

In the above section, the service profit chain construct was analysed using descriptive and inferential statistics. Items were analysed, evaluating their associations with inter-construct items, together with associations with other constructs. The opportunity now avails to empirically analyse the service profit chain in light of an association to service quality. The applicable null and alternative hypotheses are represented as:

$H 1$. Service profit chain initiatives are positively associated with service quality.

HO. Service profit chain initiatives are not positively associated with service quality.

Applicability to $\mathrm{H} 1$ is the use of the non-parametric ANOVA Kruskal-Wallis significance test (see Table IV).

Presentation of the $P$-value of 0.563 (greater than 0.05 ) represents the null hypothesis as being unlikely, therefore rejecting the null hypothesis. We therefore accept the hypothesis that service profit chain initiatives are positively associated with service quality.

\section{Table IV Test statistic ${ }^{a, b}$}

\section{Service profit chain initiatives}

\section{Chi-square}

Asymp. sig.

\section{Notes: ${ }^{a}$ Kruskal-Wallis test; ${ }^{b}$ Group variable SQ}

\section{Table IV Test statistic ${ }^{a, b}$}

\section{Conclusions}

These research results suggest the need to better understand the effects of the service profit chain on dimensions of service quality in a franchise system. Despite overall construct results indicating an appropriate satisfaction and service quality outcome, opportunity exists to synergise all the service profit chain initiatives. This research considers the implementation of service profit 
chain initiatives of retention, related sales and referrals as a key factor affecting service quality expectations. It recognises the importance of these initiatives as classifying criteria of services without the addition of adding multiple alternative dimensions, whilst limiting the evaluation to the perceptions of franchisees in a defined franchise system. Cognisance is taken of a predominant single outlet franchisee base, which in turn represents the lack of significant entrepreneurial orientation. As such, service profit chain initiatives will most likely not be forthcoming from franchisees, albeit not in a proactive mannerism.

Service profit chain links and satisfaction is the dominant association, implying significant correlation between employee and customer satisfaction. Retention and relationships are the next most dominant association, implying significant correlation between retaining customers and internal marketing.

The research identifies the emergence of gaps between service profit chain initiatives and service quality. Retention and lifetime value of customers are not adequately measured in the franchise system, implying neglect to loyal customers. SPC links and best practice initiatives are not adequately communicated in the system, an implication of poor performance management on behalf of the franchisor. Retention and feedback is depicted as inadequate in the system; implying the lack of optimal customer feedback channels. Overall, despite a few associations being inadequate within the defined franchise system, service profit chain initiatives were positively associated with service quality.

The research findings in the defined franchise system are indicative of similar outcomes to other leading service organisations (Heskett, 2002), albeit identifying dynamics within a franchise system. Overall, these dynamics are the process of relationships and behavioural aspects between franchisees and the franchisor. In addition, entrepreneurial orientation of franchisees exhibit certain intents, which in itself may influence implementation of service related initiatives. Since the franchisee is a business owner in his/her own right, it is difficult for franchisor to enforce implementation of service profit chain initiatives within the system. This in turn highlights the importance of communication and internal marketing within franchise systems, not as dominant in normal branch outlet service organisations.

\section{Managerial implications}

It appears that the application of service profit chain initiatives lead to customer satisfaction and loyalty. One must however take a holistic point of view into account, not only limiting initiatives to service quality dimensions of responsiveness, assurance, tangibility, empathy and reliability. Cognisance has to be taken of the dynamics of the franchise system, accommodating the entrepreneurial orientation and relationship paradigms which exist. 
As an example of this, we can look at the entrepreneurial orientation of franchisees. Since this system is predominantly single outlet based, franchisees fail to depict a significant entrepreneurial orientation. As such, they may lack the innovation, creativity and proactiveness required to implement service profit chain initiatives appropriately. This is where the relationship management aspect of franchise dynamics persist; in motivating, guiding, training and leading franchisees to achieve franchise system objectives. Only when the franchisees successfully implement these initiatives to achieve customer satisfaction and loyalty, will the franchise system prosper. Only franchisors with successful franchisees succeed.

Specific service profit chain implementations should be synergised within the context of the franchise system marketing plan. Key initiatives include adaptation of referral, related sales and retention strategies. These initiatives include developing and implementing a SPC programme across retention, related sales and referrals within the system; implementing measurement of loyalty within the system, particularly regarding the lifetime value of customers; developing customer feedback and complaint systems (listening posts), such as introducing a franchise toll-free number; communicating the value of SPC enhancement, and the links to profit and growth; entrenching customer value to all employees in the system, identifying the value mix and enhance SPC initiatives, such as spending time with customers, putting employees first, investing in customers and communication the message within the franchise system. The overall objective of the SPC is to link initiatives of retention, referrals and related sales with the other links within the chain. These include satisfaction, loyalty, value and long-term growth.

Related relationship associations include integrating and implementing a relationship marketing programme, consisting of customer markets, internal markets, referral markets, influence markets, supplier and alliance markets and recruitment markets; evaluating and identifying areas of discontent within the supply chain with particular emphasis to be placed on areas of trust and reciprocity between franchisees and major suppliers; developing core competencies for internal services marketing, including the measurement of franchisee satisfaction levels and developing alliances with strategic intent; such as alliance with a major take-out fast food chain such as Nando's and supply alliance with international content providers.

Service quality managerial implications include communicating technical and functional quality consumer perceptions to franchisees; instilling service quality dimensions as ongoing improvement measures within the system and setting service standards and integration of service quality relationships. This includes developing a system model of market orientation. Related implications include identifying a service quality and internal marketing link, measuring service quality within the system. 
The overall service quality objective with regard to recommendations and implications is the ultimate link to service loyalty; notwithstanding the importance of a customer centric approach. Similarly, the overall relationship marketing objective is the link to loyalty in the value and supply chain. Service quality and relationship marketing thus go hand in hand with the successful implementation of service profit chain initiatives. It is needless to say that the three concepts are mutually interdependent. Implications of the findings for managers of service organisations, and franchise systems specifically, revolve around the synergised implementation of service profit chain initiatives of retention, related sales and referrals. These initiatives are however a composite of service quality and relationship marketing within the system or organisation.

Limitations evident in the study include sampling of a defined franchise system in the home entertainment system, coupled with the majority of marketing strategies at the hand of the franchisor. Recommendations for further research include international application within the home entertainment industry, coupled with that of synergies within other related service industries. Concurrent research opportunities include the implementation of other entrepreneurial marketing initiatives, including relationship marketing and benchmarking for best practice.

\section{References}

Aaker, D.A., Kumar, V., Day, G.S. (2001), Marketing Research, 7th ed., John Wiley \& Sons, New York, NY.

Andreassen, T.W. (1994), "Satisfaction, loyalty and reputation as indicators of customer orientation in the public sector", International Journal of Public Sector Management, Vol. 7 No.2, pp.16-34.

Bahia, K., Nantel, J. (2000), "A reliable and valid measurement scale for the perceived service quality of banks", International Journal of Bank Marketing, Vol. 18 No.2, pp.84-91.

Berry, L.L., Zeithaml, V.A., Parasuraman, A. (1985), "Quality counts in services too", Business Horizons, Vol. 28 No.3, pp.44-52.

Bolton, B., Thompson, J. (2004), Entrepreneurs, Talent, Temperament, Technique, 2nd ed., Butterworth-Heinemann, Oxford..

Bygrave, W.D. (1997), The Portable MBA in Entrepreneurship, 2nd ed., John Wiley, London, .

Cronin, J.J., Taylor, S.A. (1992), "Measuring service quality: a re-examination and extension", Journal of Marketing, Vol. 56 No.7, pp.55-68.

Dillman, D.A. (2000), Mail and Internet Surveys: The Tailored Design Method, 2nd ed., John Wiley \& Sons, New York, NY.

Edwards, K. (1990), "The interplay of affect and cognition in attitude formation and change", Journal of Personality and Social Psychology, Vol. 59 pp.202-16. 
Ennew, C.T., Banerjee, A.K., Li, D. (2000), "Managing word of mouth communication: empirical evidence from India", International Journal of Bank Marketing, Vol. 18 No.2, pp.75-83.

Franceschini, F., Cignetti, M., Caldara, M. (1998), "Comparing tools for service quality evaluation", International Journal of Quality Science, Vol. 3 No.4, pp.356-67.

Gibson, R. (1998), Rethinking the Future, Nicholas Brealey, Naperville, IL.

Heskett, J.L. (2002), "Beyond customer loyalty", Managing Service Quality, Vol. 12 No.6, pp.3557.

Heskett, J.L., Sasser, W.E., Schlesinger, L. (1997), The Service Profit Chain, Free Press, New York, NY.

Heskett, J.L., Jones, T.O., Loveman, G.W., Sasser, W.E., Schlesinger, L. (1994), "Putting the service profit chain to work", Harvard Business Review, No.March-April.

Ho, C.K., Cheng, W.L. (1999), "Quest for value mix", Managing Service Quality, Vol. 9 No.3, pp.204-8.

Johnson, D.M. (2004), "In the mainstream, multi-unit and multi-concept franchising", Franchising World, No.April.

Kotler, P. (2000), Marketing Management: The Millenium Edition, Prentice-Hall, New Jersey, NJ.

Lau, R.S.M. (2000), "Quality of work life and performance- an ad hoc investigation of two key elements in the Service Profit Chain Model", International Journal of Service Industry Management, Vol. 11 No.5, pp.422-37.

Lindsay, N.J., McStay, D. (2004), "Should franchises be entrepreneurial? The influence of entrepreneurial orientation on franchise performance", paper presented at the AGSE Babson Research Exchange, Melbourne.

Malhotra, N.K., Hall, J., Shaw, M., Oppenheim, P. (2001), Marketing Research: An Applied Orientation, 2nd ed., Prentice-Hall, Frenchs Forest.

Maranto, D., Reynoso, J. (2003), "Understanding the service profit chain in Latin America: managerial perspective from Mexico", Journal of Service Quality, Vol. 13 No.2, pp.134-47.

Maritz, P.A. (2003b), "Service profit chain implementation towards achieving competitive advantage", Conference Proceedings, Australia and New Zealand Association of Management (ANZAM), Perth, December.

Maritz, P.A. (2002), "Investigating customer service levels to achieve competitive advantage", unpublished MBA dissertation, Thames Valley University, London.

Maritz, P.A. (2005a), "Entrepreneurial orientation in a franchised system", Proceedings of the 4th International Business and Economy Conference, Hawaii, January.

Maritz, P.A. (2005b), "Entrepreneurial service vision in a franchise system", unpublished doctoral thesis, University of Pretoria, Pretoria. 
Maritz, P.A., Nieman, G.H. (2005), "Innovative marketing initiatives in a franchise system", Journal of Innovative Marketing, Vol. 1 pp.21-33.

Maritz, P.A. (2003a), "Investigating customer service levels to achieve competitive advantage in the SME home entertainment rental industry", Conference Proceedings, Small Enterprise Association of Australia and New Zealand (SEAANZ), Ballarat, September.

Mendelsohn, M. (2003), The Guide to Franchising, 6th ed., Thompson Learning, London.

Michael, S.C. (2003), "First mover advantage through franchising", Journal of Business Venturing, Vol. 18 No.1, pp.61.

Palmer, A. (2001), Principles of Services Marketing, 3rd ed., McGraw-Hill, London.

Parasuraman, A., Zeithaml, V.A., Berry, L.L. (1998), "A multiple-item scale for measuring consumer perceptions of service quality", Journal of Retailing, No.March, pp.12-40.

Porter, M.E. (1998), On Competition, Harvard Business School Press, Boston, MA.

Ranaweera, C., Prabhu, A. (2003), "Some moderating effects on the service quality-customer retention link", International Journal of Operations \& Production Management, Vol. 23 No.2, pp.230-48.

Reichheld, F.F. (1996), "Learning from customer defectors", Harvard Business Review, No.March-April, pp.56-69.

Reichheld, F.F. (2001), Loyalty Rules!, Harvard Business School Press, Boston, MA.

Reichheld, F.F., Sasser, W.E. (1990), "Zero defections", Harvard Business Review, No.September-October, pp.105-11.

Ruyter, K., Bloemer, J. (1999), "Customer loyalty in extended service settings", International Journal of Service Industry Management, Vol. 10 No.3, pp.320-36.

Schvaneveldt, S.J., Enkawa, T., Miyakawa, M. (1991), "Consumer evaluation perspectives of service quality: evaluation factors and two-way model of quality", Total Quality Management, Vol. 2 No.2, pp.11-30.

Silvestro, R. (2002), "Dispelling the modern myth: employee satisfaction and loyalty drive service profitability", International Journal of Operations \& Production Management, Vol. 22 No.1, pp.3049.

Silvestro, R., Cross, S. (2000), "Applying the service profit chain in a retail environment: challenging the satisfaction mirror", International Journal of Service Industry Management, Vol. 11 No.3, pp.244-68.

Soderlund, M. (1998), "Customer satisfaction and its consequences on customer behaviour revisited", International Journal of Service Industry Management, Vol. 9 No.2, pp.169-88.

Stokes, D., Lomax, W. (2002), "Taking control of word of mouth marketing: the case of an entrepreneurial hotelier", Journal of Small Business and Enterprise Development, Vol. 9 No.4, pp.349-57. 
Sureshchandar, G.S., Rajendran, C., Anantharaman, R.N. (2002), "The relationship between service quality and customer satisfaction -a factor specific approach", Journal of Services Marketing, Vol. 16 No.4, pp.363-79.

Teas, R.K. (1993), "Expectations, performance, evaluation, and consumers' perceptions of quality", Journal of Marketing, Vol. 57 No.4, pp.18-34.

Walker, O., Boyd, H., Larreche, J. (1999), Marketing Strategy-Planning and Implementation, McGraw-Hill, Singapore.

Zeithaml, V.A., Bitner, M.J. (2003), Services Marketing, Integrating Customer Focus across the Firm, 3rd ed., McGraw-Hill-Irwin, New York, NY.

Zineldin, M. (2000), TRM Total Relationship Management, Studentlitteratur, Lund.

\section{Further Reading}

De Ryker, K., Bloemer, J. (1999), "Customer loyalty in extended service settings", International Journal of Service Industry Management, Vol. 10 No.3, pp.320-36.

\section{Corresponding author}

Alex Maritz can be contacted at: amaritz@swin.edu.au

\section{Executive summary and implications for managers}

This summary has been provided to allow managers and executives a rapid appreciation of the content of the article. Those with a particular interest in the topic covered may then read the article in toto to take advantage of the more comprehensive description of the research undertaken and its results to get the full benefit of the material present. When potential franchisees are being encouraged to start a business, they will no doubt be told that a huge advantage of franchising is that you are not "on your own" and that it is a good way of being an entrepreneur without being solely responsible for the investment of time and money in the brand.

While that is true to an extent, it is also true that a predominant single outlet franchisee might lack significant entrepreneurial orientation. As such, service profit chain initiatives will most likely not be forthcoming from franchisees, at least not in a proactive way.

Since the franchisee is a business owner in his or her own right, it is difficult for a franchisor to enforce implementation of service profit chain initiatives within the system. This in turn highlights the importance of communication and internal marketing within franchise systems.

Dr Maritz and Professor Nieman say that, despite recognition of the merits and advantages of service profit chain initiatives of retention, related sales and referrals (keeping in mind the importance of word-of-mouth) little research has empirically addressed the perceptions of franchisees regarding these initiatives. 
Retention and lifetime value of customers are not adequately measured in the franchise system, implying neglect to loyal customers. SPC links and best practice initiatives are not adequately communicated in the system, an implication of poor performance management on behalf of the franchisor. Retention and feedback is depicted as inadequate in the system, implying the lack of optimal customer feedback channels.

The paper evaluates the implementation of the service profit chain as an entrepreneurial marketing initiative within a defined franchise system (the home entertainment industry), while also evaluating these initiatives against service quality dimensions, and identifying the effect of service profit chain initiatives as perceived by franchisees. It concludes that service profit chain initiatives are positively associated with service quality.

Cognisance has to be taken of the dynamics of the franchise system, accommodating the entrepreneurial orientation and relationship paradigms which exist. Only when franchisees successfully implement initiatives to achieve customer satisfaction and loyalty, will the franchise system prosper - and only franchisors with successful franchisees succeed.

Specific service profit chain implementations should be synergised within the context of the franchise system marketing plan. Key initiatives include adaptation of referral, related sales and retention strategies.

These initiatives include developing and implementing an SPC program across retention, related sales and referrals within the system; implementing measurement of loyalty within the system, particularly regarding the lifetime value of customers; developing customer feedback and complaint systems (listening posts), such as introducing a franchise toll-free number; communicating the value of SPC enhancement, and the links to profit and growth; entrenching customer value to all employees in the system, identifying the value mix and enhance SPC initiatives, such as spending time with customers, putting employees first, investing in customers and communication the message within the franchise system.

The overall objective of the SPC is to link initiatives of retention, referrals and related sales with the other links within the chain. These include satisfaction, loyalty, value and long-term growth.

Related relationship associations include integrating and implementing a relationship marketing program, consisting of customer markets, internal markets, referral markets, influence markets, supplier and alliance markets and recruitment markets; evaluating and identifying areas of discontent within the supply chain with particular emphasis to be placed on areas of trust and reciprocity between franchisees and major suppliers; developing core competencies for internal services marketing, including the measurement of franchisee satisfaction levels and developing alliances with strategic intent.

Service quality managerial implications include communicating technical and functional quality consumer perceptions to franchisees; instilling service quality dimensions as ongoing improvement measures within the system and setting service standards and integration of service quality relationships. This includes developing a system model of 
market orientation. Related implications include identifying a service quality and internal marketing link, measuring service quality within the system.

The overall service quality objective with regard to recommendations and implications is the ultimate link to service loyalty; notwithstanding the importance of a customer centric approach. Similarly, the overall relationship marketing objective is the link to loyalty in the value and supply chain. Service quality and relationship marketing thus go hand in hand with the successful implementation of service profit chain initiatives.

Implications of the findings for managers of service organisations, and franchise systems specifically, revolve around the synergised implementation of service profit chain initiatives of retention, related sales and referrals. These initiatives are however a composite of service quality and relationship marketing within the system or organization.(A précis of the article "Implementation of service profit chain initiatives in a franchise system". Supplied by Marketing Consultants for Emerald.) 